Available online at GSC Online Press Directory

GSC Biological and Pharmaceutical Sciences

e-ISSN: 2581-3250, CODEN (USA): GBPSC2

Journal homepage: https://www.gsconlinepress.com/journals/gscbps

(REVIEW ARTICLE)

\title{
Dendritic cells vaccines: Immunotherapy against cancer
}

\author{
María Fernanda Rojas Salas ${ }^{1}$, Solano Mora Josué ${ }^{1}$, Staikidis Méndez Sofía ${ }^{1}$, Rojas Molina José Pablo ${ }^{1}$, Fung \\ Leung Wilson ${ }^{1}$, Fallas Ramírez José Manuel ${ }^{2}$ and Madrigal Redondo German ${ }^{2 *}$ \\ ${ }_{1}$ Pharmacy School, University of Costa Rica, San José, Costa Rica. \\ 2 Institute of Pharmaceutical Research (INIFAR), San José, Costa Rica.
}

Publication history: Received on 22 June 2020; revised on 19 July 2020; accepted on 22 July 2020

Article DOI: https://doi.org/10.30574/gscbps.2020.12.1.0199

\begin{abstract}
Dendritic cells are specialized cells of the innate immune system, with high capacity to present antigens in the context of the Major Histocompatibility Complex II (MHC-II) to T lymphocytes (CD4+); these cells are up to 100 times stronger than any other antigen presenting cell. The ability of the antigen presentation by dendritic cells has been documented in animal models and clinical studies conducted in humans. Based on the above, different techniques and methods have been developed to use dendritic cells in cancer-aimed immunotherapies. The dendritic cell vaccines refer to biological therapies, prepared by different strategies (ex vivo and in vivo), which aim to enhance the presentation of tumor antigens and develop a more targeted and sustained immune response on these. They are obtained from precursor cells that mature with specific stimuli that direct them to the desired therapy. Different applications for these therapies have been described in numerous types of cancers, which will be described.
\end{abstract}

Keywords: Dendritic cell; Cancer; Vaccine; Immune; Tumor

\section{Introduction}

The main function of the immune system is to protect the body from pathogens originating from microorganisms in the environment. An effective immune system must be able to detect a wide variety of pathogens and distinguish between foreign agents and the body's own tissues [1]. However, this control and surveillance system can be damaged and open the way to different diseases.

Immunotherapy seeks to obtain therapeutic benefit through mobilization of the immune system. It can be passive by transferring activated cytotoxic cells such as Lymphokine-Activated Killer (LAK) to the patient or by transferring antibodies. Also, immunotherapy can be active through vaccines [2].

Dendritic cells were discovered by Steiman Cohn in 1973 and owe their name to the fact that they can assume a variety of branched forms and they constantly expand and shrink. These cells are derived from a pluripotent stem cell located in the bone marrow. This cell results to a myeloid precursor cell that will give rise to dendritic cells that reach the tissues in an immature stage and then reach the peripheral lymphoid organs as mature cells, provided when they are stimulated [3]. Ex vivo studies have demonstrated the capacity of dendritic cells to interact with foreign antigens and present them to T cells (CD4+) in the organism, generating a clonal expansion of T cells. In addition, mature dendritic cells secrete chemokines that attract B cells, resulting in the generation of memory B cells specific for that antigen [4].

They are the most powerful antigen-presenting cells known, surpassing macrophages or B-lymphocytes. Therefore, the ability of dendritic cells to generate anti-tumor responses in vivo has been documented in animal models and in clinical

\footnotetext{
${ }^{*}$ Corresponding author: Madrigal Redondo German
}

Copyright (C) 2020 Author(s) retain the copyright of this article. This article is published under the terms of the Creative Commons Attribution Liscense 4.0. 
studies in humans [2]. As a result, the use of these cells are safe and highly effective strategies to improve the efficacy of anti-tumor therapies, in combination with other additional treatments [5].

\section{Discussion}

\subsection{Presentation of Antigens}

The innate immune system is the first line of defense against infection by microorganisms that provides an immediate and non-specific response. It responds generically to any foreign stimulus, does not confer lasting immunity and does not store immune memory. It is precisely at this stage of the immune response that dendritic cell lines of defense are included, among many others such as epithelial cells, macrophages, neutrophils, NK cells and soluble molecules like cytokines, chemokines and complement molecules [1].

Antigen presentation involves the degradation of protein antigens into peptides, which are presented in the Major Histocompatibility Complex and arranged in the plasma membrane of the antigen-presenting cells. They are then recognized by T-lymphocytes, which possess TCR receptors, which are specific to these MHC-antigen complexes. In addition to the recognition of the MHC-antigen complex, there must be an interaction between the proteins of both cells and cytokines. Depending on the type of antigen and its processing route, this can occur in either class I molecules (MHCI) or class II molecules (MHC-II). Depending on which one is present, the lymphocyte that recognizes it is different. All cells with a nucleus have MHC-I on their membrane, while MHC-II is found only in antigen-presenting cells, among which are dendritic cells [6]. Dendritic cells have the capacity to present internalized antigens derived from exogenous sources, not only by MHC class II, but also in MHC class I molecules. This is called cross presentation [7].

MHC-I presents peptides from a protein of the cell in which it is found, which is degraded in the proteasome or in the case of an infection by an intracellular parasite, pathogenic peptides may be present. The peptides after proteasome degradation are directed to the rugged endoplasmic reticulum, where they bind to the newly formed MHC-I and are exported to the cell surface by the Golgi apparatus. In contrast, MHC-II binds to exogenous antigen peptides, which were captured by the antigen-presenting cell, through endocytosis or phagocytosis [6].

\subsection{Overview of Dendritic Cells (DC)}

Dendritic cells originate from a hematopoietic stem cell CD34+ (HSC) in the bone marrow and consist of developmental and functionally distinct subsets that differentially regulate T-cell function. During inflammation and infection, the granulocyte colony-stimulating factor and macrophages (GM-CSF), is the main stimulator in the production of these [8].

When they are mature, they have a characteristic morphology, as they have membranous processes that can take the form of dendrites, pseudopodia or veils [9]. Due to these extensions, they are capable of having a large surface of contact with the environment in which they are found. This gives them the ability to capture antigens present in the environment [10].

They contain intracellular structures related to antigen processing, such as endosomes, lysosomes or Birbeck granules from the Langerhans cells of the epidermis. These cells can be found in lymphoid and non-lymphoid tissues and organs, as well as circulating in lymph and peripheral blood. They are named differently depending on the location in which they are found, but they maintain similar functions to each other $[9,11]$.

Dendritic cells are considered the most effective antigen-presenting cells in sensitizing virgin T cells to specific antigens. In addition, dendritic cells are ten to 100 times stronger in proliferating $\mathrm{T}$ cells than other antigen-presenting cells $[12,13]$.

A vaccine is a biological preparation intended to prevent or control a specific disease. Vaccines contain an agent with similar characteristics to a microorganism that causes the disease, or it is made from attenuated or dead forms of the microbe, its toxins or one of its surface proteins. This agent promotes the body's immune system to recognize the agent as foreign, then destroy it and "remember" it, so that the immune system can more easily recognize and defend against any of these microorganisms [14].

Thanks to the advances in molecular biology, there is now a wide range of vaccines, which are characterized by their efficacy and safety [15], including genetically modified attenuated vaccines, synthetic peptide vaccines, anti-idiotype vaccines, recombinant protein and peptide vaccines, gene vaccines, edible vaccines and dendritic cell vaccines $[15,16]$. 
Dendritic cell vaccines are a very powerful immunotherapeutic anti-tumor strategy. Their mechanism of action is based on the activation of an immune response capable of destroying cancer cells and on the generation of a lasting immunity. Dendritic cell vaccines make use of dendritic cell precursors, differentiation between dendritic cells and loading with tumor antigens [8].

\subsection{Characterization of Dendritic Cells (DC)}

Protocols have been created in order to obtain dendritic cells from their parents. Dendritic cells are obtained from different sources such as bone marrow, umbilical cord blood, peripheral blood and spleen in mice. The first protocol is described in 1992. It is the protocol for expanding hematopoietic precursors derived from bone marrow using GM-CSF in rats, then in mice and finally in humans [17]. The main criteria to be taken into account for the generation of DC is the source of the tissue, whether it is bone marrow, the spleen of mice or the peripheral blood of humans; the last two being the most widely used [18].

Dendritic cells are derived from leukocytes, and make a network involved in immune surveillance, antigen capture and presentation. They are predominantly found in the T-cell dependent areas of lymphoid tissue, as well as in other tissues and organs. Dendritic cells can differentiate from myeloid precursors such as blood monocytes, maturing and migrating through T-cell rich lymphatic sites, reaching nodes and the spleen, where antigen presentation occurs [19,20].

Activated dendritic cells express high levels of class I and II major histocompatibility complex (MHC) antigens. These cells are extremely potent stimulators of CD4 /CD8 T lymphocytes, the latter being critical effectors in the anti-tumor response. The dendritic cell recognizes the CD8 T-cell receptor with peptides presented in the major histocompatibility type I complex, and in CD4 T-cells, with the major histocompatibility type II complex. In addition, they express adhesion molecules (CD11a and CD54), the accessory molecules (CD40, CD80 and CD86), and induce the proliferation and differentiation of activated B cells through their CD40 antigen, as well as the expression of IL-2 and IL-12. They are not only capable of antigen presentation, but also capture and process antigens before presenting immunogenic epitopes in the context of Class I or Class II MHC molecules [19].

To promote the isolation of dendritic cells or their precursors in humans, many and varied techniques have been used. Initially, attempts were made to obtain DC precursors in peripheral blood by centrifugation in a gradient density. This method was not very useful because of the low frequency of the precursors, which constitute less than $2 \%$ of circulating mononuclear cells. Subsequently, the introduction of the apheresis technique (which consists of the extraction of blood from the patient, and subsequently its separation from the different components such as leukocytes, erythrocytes, platelets, among others) has allowed the performance of the process to be considerably improved. Large quantities of precursors are obtained to be manipulated and expanded in isolated tissues. The precursors obtained are selected from other different techniques such as immunoselection, elutriation or adhesion and are differentiated in the presence of a colony-stimulating factor (GM-CSF) and interleukin 4 [2].

\subsection{Immunotherapy}

Immunotherapy bases its efficacy on the immunogenicity of the tumor cells, and also induces a response in the cytotoxic T cells. For this to be possible, it is necessary for the cancer cells to express antigens that can become therapeutic targets. Cancers express tumor antigens that are recognized by CD4 and CD8 T lymphocytes [21,22].

The problem lies in the fact that immunotherapy has not managed to be as effective since the tumor often returns. This is because tumors have mechanisms against the immune system, such as selecting cell variants that have lost expression of immunogenic antigens or that have decreased expression of antigen presentation molecules in the major histocompatibility complex. In addition, tumors spread immunosuppressive cells that favor metastasis and tumor progression. These mechanisms are the barriers that immunotherapy encounters when it comes to fighting cancer [22].

There are several methods that immunotherapy has used to combat the disadvantages mentioned above in order to treat cancer. In surface directed immunotherapy, tumor proteins that are expressed on the surface of the cancer cell are used to target some cells of the immune system. The most commonly used proteins in this therapy are EGFR (Endothelial Growth Factor Receptor), tenascins, transferrin and IL-3 and IL-4 receptors. The disadvantage is that the duration of the immune response depends on the half-life of the cells used to target the protein. Special antibodies called biospecific antibodies have been devised to better target this therapy; this type of molecule hits a tumor cell at one end and a $\mathrm{T}$ cell at the other end, and because of the proximity between these two, the T cell will activate the immune response against the cancer cell [23]. 
Adaptive lymphocyte transfer involves isolating T cells and modifying them to attack the tumor, then injecting them back into the patient either alone or in combination with other immune cells. These can be administered systemically or directly into the tumor cavity, depending on the type of cancer being treated. There are treatments where these cells are given along with active vaccines or in conjunction with myelosuppression so that the body does not attack the modified cell. An example of this type of therapy is the use of CAR-T cells which are T cells modified to contain a monoclonal antibody that recognizes a protein expressed in the tumor cell [23].

The immune system has several checkpoints that it uses so that its activity can be regulated. Within these, two proteins are rescued, CTLA-4 and PD-1. It has been seen that if these molecules are blocked or antagonized, the response of the $\mathrm{T}$ cells can be strengthened, and they can even be made immune to the inhibitions caused by tumors. When CTLA-4 is activated, the immune response is reduced because this receptor is found on the regulatory $\mathrm{T}$ cells that modulate the immune system.

Many cancer cells can activate these receptors to escape the body's defense mechanisms. Monoclonal antibodies such as ipilimumab have been made to block these receptors and thus create an immune response that is potent but not directed at the tumor. The PD-1 receptor binds to ligands such as PDL-1 that cause the cell to go into apoptosis. Many tumor cells have the PDL-1 ligand on their surface which causes immune cells with the PD-1 to go into apoptosis. What has been done are monoclonal antibodies that block the binding between PD-1 and PDL-1 and in this way tumors can be prevented from causing leukocyte cell death [23]. This treatment has been shown to be very useful for lung cancer [24].

The vaccine is another form of treatment in immunotherapies and this involves the use of a wide spectrum of molecules. Many cancers do not have a prophylactic vaccine except for liver and cervical carcinomas. This method began by inactivating or killing the tumor cells and then injecting them into the body for recognition. Then these cells were genetically modified to produce cytokines that stimulate the immune system. One widely used cytokine is macrophagegranulocyte colony-stimulating factor. There are several types of vaccines that have been used as antigenic vaccines that consist of injecting a protein or peptide along with an adjuvant that stimulates the immune response. Another type is one that injects a series of unidentified proteins so that they stimulate the tumor cell to express proteins in the MHC1 so that the cytotoxic $\mathrm{T}$ cells can recognize it and eliminate them [23]. These are known as therapeutic vaccines and are designed to eliminate the cause of the disease, for example to kill cancer or virus-infected cells. Their activity depends mainly on specific TCD8+ that generate cytotoxic T lymphocytes [25].

Dendritic cell vaccines are also an example of this type of treatment and is the one that will be further explored in this review [23].

\subsection{Materials and methods for Obtaining DC Vaccines (Vaccine Production Process)}

With the proposal to induce an immune response against the largest amount of tumor antigens, strategies have been developed to load dendritic cells with all antigens derived from whole tumor cells. Most of the studies referred to the specialized literature that involves the isolation of DC (or its precursors), followed by a loading of tumor antigens. Causing a subsequent infusion of antigen-carrying DC [2].

In regards of dendritic cell precursors, the introduction of the apheresis technique has allowed a significant improvement in process performance, as high numbers of precursors are obtained that can be manipulated and expanded ex vivo. If the precursors obtained are monocytes, they are selected by immunoselection, elutriation or adhesion, and are subsequently differentiated in the presence of lymphocyte and macrophage colony-stimulating factor (GM-CSF) and interleukin-4 (IL-4). Bone marrow or umbilical cord blood can be used to obtain CD34+ cells, another source of precursors [2].

On the contrary, exposure to antigens can be done following different strategies. The most frequent one is the incubation of DC with peptides derived from tumor proteins restricted by the major histocompatibility complex (MHC) and with defined epitopes for the stimulation of T lymphocytes, mainly CD8+. Peptides derived from tumor antigens such as MART-1, MAGE-1, gp100, CEA, PSMA or HER-2/neu9-11 have been used for this purpose. This methodology is based on predictive algorithms that identify peptides with high affinity for the human leukocyte antigen (HLA) molecule, most commonly with the HLA*A0201 alleles. In case the epitope is not defined, the whole tumor protein can be used. This avoids restriction by a particular HLA [2]. 
Rojas Salas et al. / GSC Biological and Pharmaceutical Sciences, 2020, 12(01), 205-215

Different methods have been used to introduce the soluble proteins inside the CDs, such as microinjection, liposome mediated fusion, electroporation, or through their binding to other molecules that facilitate their transport, such as receptor fragments of the Fc portion of the immunoglobulins, bacterial toxins or viral proteins [26].

At present, different routes of vaccination based on CD have been investigated, either vaccines composed of ex-vivo generated CD loaded with different types of antigens or in-vivo developed vaccines consisting of chimeric proteins composed of an antigen (Ag) coupled with antibodies (Abs) specific to dendritic cell receptors [2].

\subsection{Strategies for Ex Vivo Trials}

As an ex vivo technique, monocytes are worked with as precursors of dendritic cells. Monocytes are routinely obtained by plastic adhesion or by immunomagnetic selection of CD14+ cells from peripheral blood mononuclear cells [10,11]. Functional DCs generated ex vivo from monocytes are applied for the stimulation of the immune response against tumor-associated antigens [27].

The ex vivo approach was developed to avoid possible impediments to therapeutic efficacy that could occur due to endogenous Dc dysfunction present in cancer patients [28]. It is a complicated technique full of difficulties, both technical and logistical.

DC are mainly obtained from peripheral blood mononuclear precursor cells (PBMC) in the presence of granulocytemacrophage colony stimulating factor (GM-CSF), interleukin-4 or interleukin-13 [25].

The difficulty of developing DC vaccines using this technique is associated with the high variability of the products due to the unpredictable and uncontrollable interindividual variation of the patients [5]. However, alternatives have been developed to prevent it.

This is a standardized strategy that is independent of the patient's blood cells. The new protocols can generate dendritic cells of the CD34 type and their derivatives, which have a superior capacity to stimulate reactive T cells towards tumors and can also activate NK cells [29]. This is intended through the use of granulocyte-macrophage colony-stimulating factor (GM-CSF), interleukin-4, tumor necrosis factor (TNF), and CD40 ligand [30].

On the other hand, there are other ex vivo DC production alternatives such as B cell cultures in the presence of CD40 ligand, resulting in a dramatic expansion of cells capable of presenting Ag with the required co-stimulatory molecules [31].

As a result, successful isolation and further expansion of mature dendritic cells allows researchers to introduce different experimental antigens into the cells. Possibly inducing an effective immune response to a malignant pathogen [5].

Early clinical trials reported that DC-based vaccines should have a "mature" state to more optimally stimulate an antigen-specific immune response from encountering $\mathrm{T}$ cells. Therefore, to enhance immunogenicity, a new generation of clinical trials has used cytokine cocktails to activate dendritic cells [32].

\subsection{In vivo Trials}

A remarkable alternative strategy is to deliver the antigens to dendritic cells directly in-vivo, by means of chimeric proteins consisting of an antibody specific to a dendritic cell receptor fused to the selected antigen. The in-vivo activation of dendritic cells represents a relevant approach, since it avoids the disadvantages of ex-vivo vaccines. Many articles have demonstrated that the in-vivo vaccine strategy induces a specific T-cell immune response that is robust and durable enough to be clinically active [33].

Dendritic cells of the DCIR, DC-SIGN, Destin, Clec9A and persistent types, along with maturation signals such as TLR3, TLR7-8, or CD40 agonists, are directly targeted to antigens through surface expressed lectins. This has contributed to stronger and more robust CD4 and CD8 T-cell immunity [34].

If this is not the case, the absence of the in-vivo approach induces antigen-specific tolerance [33]. In addition, some articles have shown that the selection of specific molecules on dendritic cells is a critical challenge to induce an effective immune response [35].

\subsection{Applications of Vaccines in the Treatment of Cancer}


Below is table I, describing the main applications of the therapy. It highlights the type of cancer, the therapy it is associated with and its specific receptor to which it is directed, as well as the method of obtaining the vaccines.

Table 1 Description of the main applications of the dendritic cells' vaccine in different cancer types

\begin{tabular}{|c|c|c|}
\hline TYPE OF CANCER & ASSOCIATED MOLECULE & MODEL DESCRIPTION \\
\hline Prostate Cancer & $\begin{array}{l}\text { Inducible CD40 receiver } \\
\text { (ihCD40r) [36]. } \\
\text { This is a DC-stimulating } \\
\text { molecule to activate a } \\
\text { response against cancer } \\
\text { cells in prostate tumors } \\
{[36] \text {. }}\end{array}$ & $\begin{array}{l}\text { A leukapheresis must first be performed for four hours so that the } \\
\text { patient's blood can be collected. Then the sample is passed through } \\
\text { different filtration procedures to obtain the mature dendritic cells. } \\
\text { Once the cells are obtained, the gene that codes for an ihCD } 40 \\
\text { receptor is transferred to them by means of the Ad5f } 35 \text { adenovirus. } \\
\text { The cells are incubated with } 10 \mu \mathrm{g} / \mathrm{mL} \text { of a protein called PA001, (a } \\
\text { protein that is expressed in the prostate membranes) to increase } \\
\text { specificity. } \\
\text { Once the mixture is obtained, rimiducid is added to preactivate the } \\
\text { DC to promote maturation and antigen presentation. } \\
\text { Once ready, the DCs are washed and cryopreserved [36]. }\end{array}$ \\
\hline Colon Cancer & $\begin{array}{l}\text { Antigen 85A (Ag85A) [37]. } \\
\text { The antigen 85A promotes } \\
\text { Th cell proliferation and } \\
\text { cytokine production. It is } \\
\text { used to potentiate the } \\
\text { dendritic cell vaccine to } \\
\text { have an anti-tumor effect } \\
\text { [37]. }\end{array}$ & $\begin{array}{l}\text { The antigen is inserted into the DC using an agent known as } \\
\text { Lipofectamine } 2000 \text { and a DNA vector called pcDNA3.1. } \\
\text { The lipofectamine was incubated with the antigen 85A for } 20 \\
\text { minutes and then added to a dendritic cell suspension. } \\
\text { The antigen enters the DC by a process known as Non-Viral } \\
\text { Lipofection Transfection. The mechanism is to use liposomes to } \\
\text { insert the genetic material as these vectors can combine with the } \\
\text { cell membrane to transfer the material [37]. }\end{array}$ \\
\hline Melanoma & $\begin{array}{l}\text { MAGE-3A1 peptide as } \\
\text { tumor antigen, and as a } \\
\text { recall and positive control } \\
\text { antigen, tetanus toxoid } \\
\text { (TT) or tuberculin }[38,39] \text {. }\end{array}$ & $\begin{array}{l}\text { A single leukapheresis is performed, } 1,000 \mu / \mathrm{mL} \text { of GM-CSF and } \\
800 \mu / \mathrm{mL} \text { of IL- }-4 \text { are added to generate monocyte differentiation } \\
\text { and then dendritic cell maturation is generated using TNF- } \alpha \text {. } \\
\text { Dendritic cells are marked with MAGE- } 3 \mathrm{~A} 1 \text { peptide as a tumor } \\
\text { antigen and either tetanus toxoid (TT) or tuberculin as a recall and } \\
\text { positive control antigen. } \\
\text { From the recall antigen, } 10 \mu \mathrm{g} / \mathrm{mL} \text { are added during the last } 24 \mathrm{~h} \text {, } \\
\text { and the MAGE-3A1 peptide is added at } 10 \mu \mathrm{M} \text { directly to the } \\
\text { cultures during the last } 8 \mathrm{~h} \text {. } \\
\text { After one week, the mature dendritic cells are collected, } \\
\text { resuspended in full medium, washed, and marked again with the } \\
\text { MAGE-3A1 peptide (now at } 30 \mu \mathrm{M} \text { ) for } 60 \text { min at } 37^{\circ} \mathrm{C} \text {. } \\
\text { Finally, the dendritic cells are washed and resuspended in PBS for } \\
\text { injection }[38,39] \text {. }\end{array}$ \\
\hline Myeloma & $\begin{array}{l}\text { Allogenic } \quad \text { apoptotic } \\
\text { myeloma cells CD138 + } \\
{[40] .}\end{array}$ & $\begin{array}{l}\text { Peripheral blood samples are taken from patients with IgA and IgG. } \\
\text { To mature DC, monocytes are cultured in IMDM (bovine serum, } \\
\text { penicillin, } 1 \% \text { streptomycin, among others), and every } 2 \text { days a } \\
\text { cytokine preparation with GM-CSF and IL-4 is added. } \\
\text { After } 6 \text { days they are induced to mature using a cocktail of } \\
\text { polarization aDC1 ((TNF- } \alpha \text { / IL-1ß / IFN- } \alpha \text { / IFN-. / poli-I: C) } \\
\text { Then, the mature cells from } \alpha \text { DC1s are loaded with apoptotic } \\
\text { CD138+ myeloma cells from the same patient. }\end{array}$ \\
\hline
\end{tabular}




\begin{tabular}{|c|c|c|}
\hline & & $\begin{array}{l}\text { These cells are isolated from bone marrow by magnetic activation } \\
\text { and after purification, they were irradiated with UV, and then } \\
\text { passed to an overnight culture [40]. }\end{array}$ \\
\hline Breast Cancer & $\begin{array}{l}\text { Synthetic peptides based } \\
\text { on the HER-2/neu } \\
\text { sequence }[41,42] .\end{array}$ & $\begin{array}{l}\text { Dendritic cells are obtained from precursors using the } \\
\text { electrophoresis technique. } \\
\text { The cells are cultured overnight at } 37^{\circ} \mathrm{C} \text { in SFM with GM-CSF and } \\
\text { IL- } 4 \text {. The next day, they are labeled with } 6 \text { promiscuous binding } \\
\text { peptides HER- } 2 / \mathrm{neu} \text { MHC class II. After } 8 \text { to } 12 \text { hours of incubation, } \\
\text { IFN- } \gamma(1000 \mathrm{U} / \mathrm{mL}) \text { is added, and the next day, } 6 \mathrm{~h} \text { before harvest, } \\
\text { the NIH reference standard LPS }(10 \mathrm{ng} / \mathrm{mL}) \text { is added to achieve } \\
\text { total activation of the dendritic cell. } \\
\text { The collected cells are washed and the batch release criteria of } \\
>70 \% \text { viability, Gram-negative staining and endotoxin }<5 \mathrm{EU} / \mathrm{kg} \text { are } \\
\text { confirmed }[41,42] \text {. }\end{array}$ \\
\hline Lung Cancer & $\begin{array}{l}\text { Cancer cells (SK-MES-1 } \\
\text { and SPC-A-1) [43]. } \\
\text { WT-1 proteins. (HLA-A2 } \\
\text { restricted to WT1 peptide, } \\
\text { CEA peptide, MAGE-1 } \\
\text { peptide) [44]. } \\
\text { In addition to the HER-2 } \\
\text { peptide [44]. }\end{array}$ & $\begin{array}{l}\text { Leukapheresis is performed and mononuclear cells are isolated by } \\
\text { centrifugation. } \\
\text { Then the SK-MES- } 1 \text { and SPC-A-1 cells are used as the antigen that } \\
\text { the dendritic cell will identify. } \\
\text { DC lysis must be performed, using ultrasound, and they are } \\
\text { centrifuged to collect the supernatant fluid that will be used to } \\
\text { direct the dendritic cell. } \\
\text { The cells are left to mature for } 7 \text { days in a solution with } \\
\text { macrophage-granulocyte stimulating factor, interleukin } 4 \text { and } \\
\text { tumor necrosis factors for } 9 \text { days. } \\
\text { The DCs were isolated by means of Ficoll-Hypaque density gradient } \\
\text { centrifugation. Then centrifugation with hyperosmotic density } \\
\text { gradient of Percoll, followed by two hours of adherence to the } \\
\text { culture in plate. } \\
\text { Monocyte cultures are grown in RMPI medium with } 1 \% \\
\text { penicillin/streptomycin, glutamine, } 10 \% \text { autologous, GM-CSF and } \\
\text { IL- } 4 \text { for } 6 \text { days. } \\
\text { After } 9 \text { days, the dendritic cell culture is loaded with HLA-A2 } \\
\text { restricted to WT1 peptide, CEA peptide, MAGE- } 1 \text { peptide and HER- } \\
2 \text { peptide at a concentration of } 25 \mu \mathrm{g} / \mathrm{mL} \text { and incubated for } 24 \\
\text { hours [43-45]. }\end{array}$ \\
\hline Glioblastoma & $\begin{array}{l}\text { EGFRvIII, gp100, survivin } \\
\text { and telomerase proteins } \\
{[46,47] \text {. }}\end{array}$ & $\begin{array}{l}\text { A leukapheresis is performed to isolate the DCs, they are washed } \\
\text { with PBS/EDTA and the isolated is centrifuged. A hemogram is } \\
\text { made and the leukocytes are cultured. } \\
\text { Tumor tissues are taken and mechanically dispersed with } \\
\text { increasingly smaller needles. The tissue is suspended in PBS and } \\
\text { centrifuged. The pellets (resulting from the centrifugation) are then } \\
\text { caught and resuspended in PBS and percolated on a filter. The } \\
\text { filtrate is centrifuged and sounded in a bath for } 1 \text { hour. When the } \\
\text { tumor proteins are obtained, they are pulsed into the dendritic cells } \\
\text { on the fifth day. } \\
\text { On the sixth day the dendritic cells are cultured with pro- } \\
\text { inflammatory cytokines such as TNF- } \alpha \text {, interleukin-1 and } \\
\text { prostaglandins E. The loaded dendritic cells are then collected and } \\
\text { frozen in a solution with NaCl, dimethyl sulfoxide and human } \\
\text { albumin }[46,47] \text {. }\end{array}$ \\
\hline
\end{tabular}




\begin{tabular}{|l|l|l|}
\hline $\begin{array}{l}\text { Pancreatic } \\
\text { Cancer }\end{array}$ & $\begin{array}{l}\text { MAGE-A3 (melanoma } \\
\text { antigen family A, 3) [48]. } \\
\text { Wilms Tumor Gene 1 } \\
\text { (WT1) and peptides } \\
\text { (TLP0-001) [49]. }\end{array}$ & $\begin{array}{l}\text { Monocytes are grown by apheresis of the patient's blood. Their } \\
\text { differentiation is induced, and they are marked with tumor } \\
\text { antigenic peptides. } \\
\text { For TLP0-001 injection, the frozen product contains 1 } 107 \text { live } \\
\text { dendritic cells per 1 mL of solution, it is thawed before use [48,49]. }\end{array}$ \\
\hline Ovarian Cancer & $\begin{array}{l}\text { HER-2/neu, p53, NY-ESO- } \\
\text { CDR2, hTERT, } \\
\text { mesotheline, survivina SP- } \\
\begin{array}{l}17, \text { WT1, among others } \\
{[50] .}\end{array}\end{array}$ & $\begin{array}{l}\text { The DC is obtained from the patient and differentiated by apheresis. } \\
\text { It is placed in the presence of granulocyte and macrophage colony- } \\
\text { stimulating factor and interleukin 4, for 7 days. With the purpose of } \\
\text { promoting the differentiation of DC. } \\
\text { Different epitopes are taken for CD8+ cytotoxic T cells and for CD4+ } \\
\text { Thelper (Th) cells. } \\
\text { They are marked with the cells Her-2/neu, p53, NY-ESO-1, CDR2, } \\
\text { hTERT, mesotheline, survivin SP-17, WT1, to induce the specific } \\
\text { response on these antigens [50]. }\end{array}$ \\
\hline
\end{tabular}

\section{Conclusion}

The immune system plays a very important role for human beings since it defends them from microorganisms or other harmful agents. However, you can use this naturally occurring defense mechanism and modify it to treat cancer and other diseases, which is what immunotherapy is all about. As a result, dendritic cell vaccines have been shown to be quite effective in treating cancer patients since by using the person's own immune system, the adverse effects are dramatically reduced because the problem of rejection will not occur. In addition, the dendritic cell is very specific in recognizing antigens and can therefore ensure that it specifically attacks tumor cells as long as the cell has been previously treated to recognize them.

The tumor's ability to generate immune system evasion can also be combated. The production of these vaccines can be a very important tool to treat cancer and thus increase the possibility of patient survival, especially in the most dangerous tumors such as glioblastoma.

\section{Compliance with ethical standards}

\section{Acknowledgments}

This research work was carried out during the course Fundamentos de Biotecnología. We would like to thank Dr. Juan José Mora, coordinator of the course, and Dr. José Manuel Fallas, collaborating professor, for their support and for guiding this research.

\section{Disclosure of conflict of interest}

The Author declare no conflict of interest.

\section{References}

[1] Muñoz MA, García MD and Reguera RM. (2017). Nanotecnología. Nanomedicina e Infección por el Virus de la Inmunodeficiencia Humana. Nanotecnología y células dendríticas en el desarrollo de una vacuna terapéutica frente al VIH, First edition. Programa Iberoaméricano de Ciencia y Tecnología para el Desarrollo, Madrid, 46.

[2] Sureda M, Vázquez MB and Rebollo J. (2012). Células dendríticas II: utilización clínica en vacunación antitumoral. Inmunología, 31(2), 43-48.

[3] Lozada I, Núñez C and Aguilar JL. (2015). Inmunoterapia en melanoma: vacunas de células dendríticas. Revista Peruana de Medicina Experimental y Salud Pública, 32 (2), 555. 
Rojas Salas et al. / GSC Biological and Pharmaceutical Sciences, 2020, 12(01), 205-215

[4] Pyzer AR, Avigan DE and Rosenblatt J. (2014). Clinical trials of dendritic cell-based cancer vaccines in hematologic malignancies. Human Vaccines Immunotherapy, 10(11), 3125-3131.

[5] Galati D and Zanotta S. (2017). Hematologic neoplasms: Dendritic cells vaccines in motion. Clinical Immunology, 183, 181-190.

[6] Alfaro C, Oñate C, Rodríguez A, Pérez JL, Fernández M and Melero I. (2013). Células dendríticas especializadas en presentación de antígenos exógenos a linfocitos T citotóxicos. Anales del Sistema Sanitario de Navarra, 36(3), 519-537.

[7] Bol KF, Schreibelt G, Gerritsen WR, de Vries IJM and Figdor CG. (2016). Dendritic Cell-Based Immunotherapy: State of the Art and Beyond, Clinical Cancer Research, 22(8), 1897-1906.

[8] Constantino J, Gomes C, Falcão A, Neves BM and Cruz MT. (2017). Dendritic cell-based immunotherapy: a basic review and recent advances. Immunology Research, 65(4), 798-810.

[9] Vázquez MB, Sureda M and Rebollo J. (2012). Células dendríticas I: aspectos básicos de su biología y funciones. Inmunología, 31(1), 21-30.

[10] Rizzo M, Alaniz L and Mazzolini G. (2016). Vacunas Terapéuticas Antitumorales basadas en Células Dendríticas. Medicina Buenos Aires, 76(16), 307-314.

[11] Romero F, Sánchez P, Risalde MA, Pedrera M, Molina V, Ruiz E and Gómez JC. (2011). Funciones y clasificación de las células dendríticas. Anales de la Real Academia de Ciencias Veterinarias de Andalucía Oriental, 24(1), 168185.

[12] Cintolo JA, Datta J, Mathew S and Czerniecki BJ. (2012).Dendritic cell-based vaccines: barriers and opportunities. Future Oncology, 8(10), 1273-1299.

[13] Sabado RL, Balan S and Bhardwaj N. (2017). Dendritic cell-based immunotherapy, Cell Research, 27(1), 74-95.

[14] Donnelly RF. (2017). Vaccine delivery systems. Human Vaccines Immunotherapy, 13(1), 17-18.

[15] López M, Mallorquín P, Pardo R and Vega M. (2004). Vacunas de nueva generación: informe de vigilancia tecnológica. Genoma España, Madrid, 52-56.

[16] Baxter D. (2007). Active and passive immunity, vaccine types, excipients and licensing. Occupational Medicine, $57(8), 552-556$.

[17] Seager J, Lutz M, Hama S, Cruz D, Castrillo A, Lazaro J, Phillips R, Premack B and Berliner J. (2004). Method for large scale isolation, culture and cryopreservation of human monocytes suitable for chemotaxis, cellular adhesion assays, macrophage and dendritic cell differentiation. Journal of Immunological Methods, 288(1) 123134.

[18] Howard CJ and Hope JC. (2000). Dendritic cells, implications on function from studies of the afferent lymph veiled cell. Veterinary Immunology and Immunopathology, 77(1), 1-13.

[19] Yamanaka R and Kajiwara K. (2012). Dendritic Cell Vaccines. Glioma: Advances in Experimental Medicine and Biology. Springer, New York, 187-200.

[20] Filley AC and Dey M. (2017). Dendritic cell based vaccination strategy: an evolving paradigm, Journal of NeuroOncology, 133(2), 223-235.

[21] Wculek SK, Amores J, Conde R, Khouili SC, Melero I and Sancho D. (2019). Effective cancer immunotherapy by natural mouse conventional type-1 dendritic cells bearing dead tumor antigen, Journal for Immunotherapy of Cancer, 7(1), 100.

[22] Gato M, Liechtenstein T, Blanco I, Zudaire MI, Kochan G and Escors D. (2015). Inmunoterapia genética con células dendríticas para el tratamiento del cáncer. Anales del Sistema Sanitario de Navarra, 38 (2), 279-287.

[23] Fecci PE, Heimberger AB and Sampson JH. (2014). Immunotherapy for Primary Brain Tumors: No Longer a Matter of Privilege. Clinical Cancer Research, 20(22), 5620-5629.

[24] Pu X, Wu L, Su D, Mao W and Fang B. (2018). Immunotherapy for non-small cell lung cancers: biomarkers for predicting responses and strategies to overcome resistance, BMC Cancer, 18(1), 1082.

[25] Palucka K and Banchereau J. (2013). Dendritic-Cell-Based Therapeutic Cancer Vaccines. Immunity, 39(1), 38-48.

[26] Haicheur N, Bismuth E, Bosset S, Adotevi O, Warnier G, Lacabanne V, Regnault A, Desaymard C, Amigorena S, Ricciardi P, Goud B, Fridman WH, Johannes L and Tartour E. (2000). The B Subunit of Shiga Toxin Fused to a 
Rojas Salas et al. / GSC Biological and Pharmaceutical Sciences, 2020, 12(01), 205-215

Tumor Antigen Elicits CTL and Targets Dendritic Cells to Allow MHC Class I-Restricted Presentation of Peptides Derived from Exogenous Antigens. The Journal of Immunology, 165(6), 3301-3308.

[27] Mody N, Dubey S, Sharma R, Agrawal U and Vyas SP. (2015). Dendritic cell-based vaccine research against cancer. Expert Review of Clinical Immunology, 11(2), 213-232.

[28] Pinzon A, Maxwell T and López JA. (2005).Dendritic cell dysfunction in cancer: A mechanism for immunosuppression. Immunology and Cell Biology, 83(5), 451-461.

[29] Thordardottir S, Schaap N, Louer E, Kester MGD, Falkenburg JHF, Jansen J, Radstake TRD, Hobo W and Dolstra H. (2017). Hematopoietic stem cell-derived myeloid and plasmacytoid DC-based vaccines are highly potent inducers of tumor-reactive T cell and NK cell responses ex vivo. OncoImmunology, 6(3), e1285991.

[30] Zeng J, Wu C and Wang S. (2015). Antigenically Modified Human Pluripotent Stem Cells Generate AntigenPresenting Dendritic Cells. Scientific Reports, 5(1), 15262.

[31] Kinnebrew MA, Buffie CG, Diehl GE, Zenewicz LA, Leiner I, Hohl TM, Flavell RA, Littman DR and Pamer EG. (2012). Interleukin 23 Production by Intestinal CD103+CD11b+ Dendritic Cells in Response to Bacterial Flagellin Enhances Mucosal Innate Immune Defense. Immunity, 36(2), 276-287.

[32] Dougan M, Dranoff G and Dougan SK. (2019). Cancer Immunotherapy: Beyond Checkpoint Blockade. Annual Review of Cancer Biology, 3(1), 55-75.

[33] Bonifaz LC, Ponnyay DP, Charalambous A, Darguste DI, Fujii SI, Soares H, Brimnes MK, Moltedo B, Moran TM and Steinman RM. (2004). In vivo targeting of antigens to maturing dendritic cells via the DEC-205 receptor improves T cell vaccination. The Journal of Experimental Medicine, 199(6), 815-824.

[34] Tacken PJ and Figdor CG. (2011). Targeted antigen delivery and activation of dendritic cells in vivo: Steps towards cost effective vaccines. Seminars in Immunology, 23(1), 12-20.

[35] Soares H, Waechter H, Glaichenhaus N, Mougneau E, Yagita H, Mizenina O, Dudziak D, Nussenzweig MC and Steinman RM. (2007). A subset of dendritic cells induces CD4+ T cells to produce IFN- $\gamma$ by an IL-12-independent but CD70-dependent mechanism in vivo. Journal of Experimental Medicine, 204(5), 1095-1106.

[36] Sonpavde G, McMannis JD, Bai Y, Seethammagari MR, Bull JMC, Hawkins V, Dancsak TK, Lapteva N, Levitt JM, Moseley A, Spencer DM and Slawin KM. (2017). Phase I trial of antigen-targeted autologous dendritic cell-based vaccine with in vivo activation of inducible CD40 for advanced prostate cancer. Cancer Immunology, Immunotherapy, 66(10), 1345-1357.

[37] Zhai J, Gao W, Zhao L, Gao Z, Jiang X and Lu C. (2018). Dendritic cell vaccine with Ag85A enhances anti-colorectal carcinoma immunity. Experimental and Therapeutic Medicine, 16, 5123-5129.

[38] Thurner B, Haendle I, Röder C, Dieckmann D, Keikavoussi P, Jonuleit H, Bender A, Maczek C, Schreiner D, von den Driesch P, Bröcker EB, Steinman RM, Enk A, Kämpgen E and Schuler G. (1999). Vaccination with Mage-3a1 Peptide-Pulsed Mature, Monocyte-Derived Dendritic Cells Expands Specific Cytotoxic T Cells and Induces Regression of Some Metastases in Advanced Stage IV Melanoma. The Journal of Experimental Medicine, 190(11), 1669-1678.

[39] Gaugler B, Van den Eynde B, van der Bruggen P, Romero P, Gaforio JJ, De Plaen E, Lethé B, Brasseur F and Boon T. (1994). Human gene MAGE-3 codes for an antigen recognized on a melanoma by autologous cytolytic $\mathrm{T}$ lymphocytes. The Journal of Experimental Medicine, 179(3), 921-930.

[40] Yang DH, Kim MH, Lee YK, Hong CY, Lee HJ, Nguyen TN, Bae SY, Ahn JS, Kim YK, Chung IJ, Kim HJ, Kalinski P and Lee JJ. (2011). Successful cross-presentation of allogeneic myeloma cells by autologous alpha-type 1-polarized dendritic cells as an effective tumor antigen in myeloma patients with matched monoclonal immunoglobulins. Annals of Hematology, 90(12), 1419-1426.

[41] Sharma A, Koldovsky U, Xu S, Mick R, Roses R, Fitzpatrick E, Weinstein S, Nisenbaum H, Levine BL, Fox K, Zhang P, Koski G and Czerniecki BJ. (2012). HER-2 pulsed dendritic cell vaccine can eliminate HER-2 expression and impact ductal carcinoma in situ: DC Vaccine Eliminates HER-2 Expression. Cancer, 118(17), 4354-4362.

[42] Czerniecki BJ, Koski GK, Koldovsky U, Xu S, Cohen PA, Mick R, Nisenbaum H, Pasha T, Xu M, Fox KR, Weinstein S, Orel SG, Vonderheide R, Coukos G, DeMichele A, Araujo L, Spitz FR, Rosen M, Levine BL, June C and Zhang PJ. (2007). Targeting HER-2/neu in Early Breast Cancer Development Using Dendritic Cells with Staged Interleukin12 Burst Secretion. Cancer Research, 67(4), 1842-1852. 
[43] Zhang L, Yang X, Sun Z, Li J, Zhu H, Li J and Pang Y. (2016). Dendritic cell vaccine and cytokine-induced killer cell therapy for the treatment of advanced non-small cell lung cancer, Oncology Letters, 11(4), 2605-2610.

[44] Perroud MW, Honma HN, Barbeiro AS, Gilli SC, Almeida MT, Vassallo J, Saad ST and Zambon L. (2011). Mature autologous dendritic cell vaccines in advanced non-small cell lung cancer: a phase I pilot study. Journal of Experimental \& Clinical Cancer Research, 30(1), 65.

[45] Takahashi H, Shimodaira S, Ogasawara M, Ota S, Kobayashi M, Abe H, Morita Y, Nagai K, Tsujitani S, Okamoto M, Suzuki Y, Nakanishi Y and Yonemitsu Y. (2016). Lung adenocarcinoma may be a more susceptive subtype to a dendritic cell-based cancer vaccine than other subtypes of non-small cell lung cancers: a multicenter retrospective analysis. Cancer Immunology, Immunotherapy, 65(9), 1099-1111.

[46] Nava S, Dossena M, Pogliani S, Pellegatta S, Antozzi C, Baggi F, Gellera C, Pollo B, Parati EA, Finocchiaro G and Frigerio S. (2012). An Optimized Method for Manufacturing a Clinical Scale Dendritic Cell-Based Vaccine for the Treatment of Glioblastoma. PLoS ONE, 7(12), e52301.

[47] Reardon DA and Mitchell DA. (2017). The development of dendritic cell vaccine-based immunotherapies for glioblastoma. Seminars in Immunopathology, 39(2), 225-239.

[48] Batchu RB, Gruzdyn OV, Qazi AM, Mahmud EM, Mostafa G, Weaver DW and Gruber SA. (2016). Pancreatic Cancer Cell Lysis by Cell-Penetrating Peptide-MAGE-A3-Induced Cytotoxic T Lymphocytes. JAMA Surgery, 151(11), 1086.

[49] Katsuda M, Miyazawa M, Ojima T, Katanuma A, Hakamada K, Sudo K, Asahara S, Endo I, Ueno M, Hara K, Yamada S, Fujii T, Satoi S, Ioka T, Ohira M, Akahori T, Kitano M, Nagano H, Furukawa M, Adachi T and Yamaue H. (2019). A double-blind randomized comparative clinical trial to evaluate the safety and efficacy of dendritic cell vaccine loaded with WT1 peptides (TLP0-001) in combination with S-1 in patients with advanced pancreatic cancer refractory to standard chemotherapy. Trials, 20(1), 242.

[50] Kandalaft LE, Chiang CL, Tanyi J, Motz G, Balint K, Mick R and Coukos G. (2013). A Phase I vaccine trial using dendritic cells pulsed with autologous oxidized lysate for recurrent ovarian cancer. Journal of Translational Medicine, 11(1), 149.

\section{How to cite this article}

Rojas Salas F, Solano Mora J, Staikidis Méndez S, Rojas Molina JP, Fung Leung W, Fallas Ramírez JM and Madrigal Redondo G. (2020). Dendritic cells vaccines: Immunotherapy against cancer. GSC Biological and Pharmaceutical Sciences, 12(1), 205-215. 